\section{Integration, conflict, and autonomy among religious minorities in the late 0ttoman Empire: the Greek-Catholic (Melkite) Church and sectarian turmoil in Mount Lebanon and Damascus}

Integración, conflicto y autonomía entre las minorías religiosas a finales del Imperio Otomano: la Iglesia grecocatólica (melquita) y la agitación sectaria en el Monte Líbano y Damasco

Integração, conflito e autonomia entre as minorias no fim do Império Otomano: a Igreja Greco-Católica (Melquita) e os confrontos sectários no Monte Líbano e em Damasco

Youssef Alvarenga Cherem'

Danny Zahreddine²

DOI: 10.5752/P.2317-773X.2020v8.n4.p59

Received in: September 04, 2020

Accepted in: November 16, 2020

\begin{abstract}
The $19^{\text {th }}$ century was a time of social and political upheaval for the Ottoman Empire. To contend with dwindling territories, uprisings, unrest, and international military, political, and economic pressure, it had to overcome structural deficiencies in the armed forces, economy, and State bureaucracy that kept it lagging behind its European counterparts. The modernizing impetus ultimately took the form of full-fledged legal and institutional reform by mid-century, transforming but also unsettling the Ottoman State and society. In this article we discuss a central component of those reforms and of the international relations of the Ottoman Empire in the nineteenth century: the legal status of non-Moslem minorities. We frame our discussion in the analysis of two moments: the official recognition of the Greek-Catholic (Melkite) religious community in 1848 and the sectarian civil conflict in Mount Lebanon and Damascus in 1860. The intersecting vectors of economic religious and political interests in their local, regional and international dimensions will be fleshed out, evincing a more nuanced and multilayered, and less monolithic and state-centered, approach toward the international relations of the late Ottoman Empire and the working of its institutions.
\end{abstract}

1. BA in International Relations from the Pontifical Catholic University of Minas Gerais (2003), MA and PhD in Social Anthropology from the State University of Campinas $(2005,2010)$, currently teaching at the Federal University of São Paulo. His research focuses chiefly on the History of the Middle East, Islam, and anthropology of religion. ORCID: https://orcid.org/0000-0003-2516-9657

2. BA in International Relations from the Pontifical Catholic University of Minas Gerais, MA and PhD in Geography from the Postgraduate Program in Spatial Information Treatment (PUC Minas). Professor at the Department of International Relations at PUC Minas and a permanent member of the Postgraduate Program in International Relations (PUC Minas). Leader of the Middle East and Maghreb Study Group - CNPq (GEOMM) ORCID: https://orcid.org/0000-00017400-0300. 


\section{RESUMEN}

El siglo XIX fue una época de agitación social y política para el Imperio Otomano. Para hacer frente a territorios perdidos, levantamientos, presiones y disturbios militares, políticos y económicos internacionales, tuvo que superar las deficiencias estructurales en las fuerzas armadas, la economía y la burocracia estatal que lo mantenían detrás de sus homólogos europeos. El impulso modernizador terminó tomando la forma de una profunda reforma legal e institucional a mediados de siglo, transformando, pero también perturbando, el estado y la sociedad otomanos. En este artículo, discutimos un componente crucial de estas reformas y relaciones internacionales en el Imperio Otomano del siglo XIX: el estatus legal de las minorías no musulmanas. Incluimos nuestro debate en el análisis de dos momentos: el reconocimiento oficial de la comunidad religiosa greco-católica (melkita) en 1848 y el conflicto civil sectario en Monte Líbano y Damasco en 1860. Discutiremos los vectores de intersección de intereses económicos, religiosos y políticos en su dimensión local, regional e internacional, mostrando un enfoque más matizado y multifacético y menos monolítico y estatocéntrico de las relaciones internacionales del Imperio Otomano tardío y el funcionamiento de sus instituciones.

Palabras clave: Imperio Otomano. Religión. Líbano. Siria. Melquitas. Drusos.

\section{RESUMO}

O século XIX foi uma época de turbulência social e política para o Império Otomano. Para lidar com perda territórios, levantes, distúrbios e pressões militares, políticas e econômicas internacionais, ele teve de superar as deficiências estruturais nas forças armadas, na economia e na burocracia do Estado que o mantiveram atrasado em relação aos seus homólogos europeus. O ímpeto modernizador acabou assumindo a forma de uma profunda reforma jurídica e institucional em meados do século, transformando, mas também perturbando, o Estado e a sociedade otomanos. Neste artigo, discutimos um componente crucial dessas reformas e das relações internacionais do Império Otomano no século XIX: o status jurídico das minorias não muçulmanas. Enquadramos nossa discussão na análise de dois momentos: $\mathrm{O}$ reconhecimento oficial da comunidade religiosa greco-católica (melquita) em 1848 e o conflito civil sectário no Monte Líbano e Damasco em 1860. Os vetores de intersecção de interesses econômicos, religiosos e políticos em suas dimensões locais, regionais e internacionais serão iluminados, evidenciando uma abordagem mais matizada e multifacetada e menos monolítica e estatocêntrica em relação às relações internacionais do Império Otomano tardio e ao funcionamento de suas instituições.

Palavras-chave: Império Otomano. Religião. Líbano. Síria. Melquitas. Drusos

3. Throughout this text we have opted to employ a simplified transliteration of Arabic words and names. Diacritics have been suppressed, and long vowels, where needed, are marked as a grave accent (^). Hamza is marked by a closing single quote mark (') and 'ayn, by an opening single quote mark ('). Proper nouns follow the most usual spelling in English.
Introduction: The Ottoman Empire and the "Eastern Question"

The twilight of the eighteenth century did not bode well for the prospects of the ruling House of Uthman in the coming decades, which witnessed constant setbacks at the hands of European powers. The Ottomans were pushed to make an alliance with Great Britain against the French in Egypt (1798-1801), defeated in the long war for Greek independence (18221829), then against their nominal subject, Muhammad ${ }^{3}$ (Mehmet) Ali, ruler of Egypt, whose dominions extended to most of the Ottoman Middle East possessions and Sudan. Mehmet Ali's army was only held back in Syria by dint of British intervention. By then, both the Ottomans and the Egyptian Khedive had soon realized that their destiny lied increasingly in their ability to adapt, modernizing its army and State apparatus along the lines of their European counterparts. The roots of reform lie earlier, in the ex- 
tinction of the Janissaries in 1826 and the formation of a modern army (Nizam-e Jedid), and even before, in the massacre of the Mamluks by Mehmet Ali in Cairo in 1811 and his far-reaching state-building reforms, but much of the modernizing impetus that was to prove so momentous for future developments was fostered by Sultan Abdulmejid I (reigned 1839-1861) and continued under his brother and successor Abdulaziz (r. 1861-76).

The reforms needed to face the geopolitical and economic challenge meant a total overhaul of the Ottoman State apparatus through modernization (new law codes, ministries, a new bureaucracy structure, reform of the armed forces, a new taxation system, new land laws, etc.) and the creation of an economic infrastructure (railways, ports, postal service, banks, urbanization and industrialization).

Starting in the 16th century, the Ottoman Empire lagged behind other European powers in terms of State revenue, a situation which is congruent to their relative deficit in armed power and a series of military setbacks in the eighteenth century (KARAMAN; PAMUK, 2010). The tax-farming system syphoned revenue away from the State. For a population of around 20 million in the Balkans and Anatolia, it was estimated that by 1809 State revenue "scarcely equalled 2.25 million British pounds [...] By comparison, Britain, with only 9.5 million inhabitants in 1787-90 had an average annual revenue of 16.8 million pounds, while France with a population of 24 million had revenues equal to 18 million pounds in 1787 and 24 million pounds in 1789" (LEVY, 1982, p. 239). Moreover, according to Findley (2012, p. 56), the Ottoman bureaucracy totaled between a paltry 1,000 and 1,500 scribes by the end of the eighteenth century.

The difficulty was compounded by rising costs of increasing and maintaining a modern army, and inflation. ${ }^{4}$ Military reform depended on fiscal (SHAW, 1975; KARAMAN; PAMUK, 2010), bureaucratic (FINDLEY, 2012), and economic modernization - all of which were interdependent. A crucial aspect was how to deal with concomitant rising costs and plummeting revenue due to inflation:

\footnotetext{
The Ottoman economy went through one of its worst periods between 1770 and 1840. Adjusted for inflation, government expenditures may have tripled under Selim and Mahmud. The government could not cope without reorganizing and centralizing its finances. Still the effects of crisis were felt at all levels of the economy, and Mahmud II carried out the most drastic coinage debasements in Ottoman history (FINDLEY, 2010, p. 49).
}

The reformist wave was characteristically spearheaded by the sector linked to the government's foreign relations. The reforms undertaken by Sultan Abdulmejid I (r. 1839-1861) and his brother Abdulaziz I (r. 186176) were implemented by the cosmopolitan elite, dubbed by Bunton and Cleveland (2009) as the "French knowers" (in fact, Abdulmejid I himself spoke French, and Abdulaziz was the first sultan to visit Western Europe).

Momentous changes were brought about by the expansion of the European State system, the capitalist economy (the free-trade Anglo-Ottoman Treaty of 1838) and nationalism (autonomy and later independence of the European provinces). The Ottoman Empire was deeply affected by these trends, both within the power structure and regarding the Sublime Porte's relation to its subjects, throughout the 19th century. The entrance of the Ottoman Empire in the "European Concert" (Treaty of Paris, 1856) inaugurates a pe-
4. In an ironic twist of history, "Ottoman society rejected westernizing reform in the reign of Selim III, but the same society accepted it, in a definitive and irreversible manner, less than two decades later, in the reign of Mahmud II (1808-1839)." (LEVY, 1982, p. 242). 
5. In hindsight, one could easily dismiss and explain away the Melkite union with the Roman Catholic Church and its subsequent recognition as an autonomous millet by the Ottoman Empire as simply a result of European political, economic and religious encroachment upon native religious communities, just one in a series of Churches in the Middle East that split and united with

Rome (whence its slightly derogatory epithet "Uniate Churches"). However, as we shall endeavor to demonstrate, the Melkite case presents its own cultural and religious peculiarities, which cannot be wholly subsumed into an economic or political explanation of foreign influence. Local and regional dynamics (in politics, economy, and society) must be given pride of place side by side broader Mediterranean confluences with the European powers. Moreover, the development of the Melkite Church and its community has been taken as a mere backdrop for other, more momentous developments, such as the creation of autocephalous (i.e., autonomous) Orthodox Churches in the Balkans in the latter half of the 19th century. riod of thorough institutional reforms, known as Tanzimat, whose goal was to modernize the State to face the long decline of the Empire's relative power on the European stage. One of the key constituents of the process of "reorganization" or "restructuring" (whence the meaning of the word "Tanzimat"), was the improved legal status of its non-Muslim subjects, enacted with the direct participation of European powers in the drafting of their decrees - the Edict of Gülhane of 1839 and the Reform Edict of 1856. It is important to bear in mind that, although the Ottoman Empire had become a recognized actor in international society and has never been directly colonized or completely dominated by European powers, its very survival depended on a delicate interplay between autonomy, reforms and international alliances, and its status as a "second-class member" of the European Concert derives both from its military and economic fragility and from the European balance of power (Austria-Hungary, United Kingdom, France, Prussia / Germany, and Russia).

The Tanzimat period (1839-1876), the subsequent period of authoritarianism under Sultan Abdulhamid (r. 1876-1909), as well as the turbulent period of the Young Turks Revolution (1909) and the First World War can be seen as permeated by the interdependence of international relations and the Ottoman political system. As symbolic and economic exchanges with the West deepened, structures and attitudes towards modernity, as well as political currents, that emerged during this period would inform future generations.

In this context, interreligious relations are a privileged locus, a "prism" for a reading of the modernization process and creation of modern states in the aftermath of the collapse of the Ottoman Empire. Issues that arose during or immediately after this "long 19th century" are at the root of modernization and state-building processes in Europe (Balkans, Central and Eastern Europe) and the Middle East and North Africa.

In this article, we will deal specifically with one of the main vectors of autonomy vis à vis the central administration of the Empire, constituting a crucial and sensitive feature of the internal and international political landscape of the Ottoman Empire - the issue of non-Muslim "minorities". We shall first briefly sketch the symbolic and institutional field that defined these relations within the scope of the religious and legal practices of Islam and regarding the political reforms of the Ottoman Empire in the 19th century. The traditional hierarchical form of social and political organization in the Empire will undergo profound changes during the 19th century, under European influence and internal reforms, in the shadow of monumental economic and geopolitical challenges.

We shall then turn our attention to two case studies: the seemingly inconsequential ${ }^{5}$ and often overlooked establishment of the Melkite millet in 1848 and the momentous sectarian conflicts in Mount Lebanon in 1860 as events that both reflected and helped shape the course of modernization and integration with the Western international/economic order. In both cases we witness the dialectic between integration, conflict, and autonomy, in a delicate negotiation between communities and local authorities, the center of power in Constantinople, and the European powers directly or indirectly involved in this process. Finally, we conclude considering the impacts, continuities, and ruptures established in this process, which still echo in the social, political, and symbolic structure in some countries in the Middle East. 
Islamic attitudes toward other religions

The issue of tolerance of Islam toward other religions has been extensively discussed (FRIEDMANN, 2003; CRONE, 2009; DERINGIL, 2000; GODDARD, 2000; SHARKEY, 2017; LITTLE, 1976; O’SULLIVAN, 2006; BAER; MAKDISI; SHRYOCK, 2009; BRAUDE; LEWIS, 1982, inter alia). Among its most public and political features, some brief comments are in order. Apologists of all hues, whether Muslim or not, are prone to quote verse 2:256 of the Koran:

\begin{abstract}
No compulsion is there in religion. Rectitude has become clear from error. So whosoever disbelieves in idols and believes in God, has laid hold of the most firm handle, unbreaking; God is All-hearing, All-knowing [Tr. Arberry]
\end{abstract}

Yet, the hermeneutical issue is not so easily settled. According to Crone (2009), there are several traditional interpretations of this verse (which were subsequently carried over or modified by modern exegetes):

- It was abrogated, because it had appeared at a time when Muhammad should compromise with the population of Mecca, since he had no power at the time.

- It was historically restricted and irrelevant afterwards: it only meant that Muslims in Medina, at the time of the revelation should not try to force their children to convert.

- It only applied to the so-called Peoples of the Book ("Ahl al-Kitab"). The "pagans" only had two options, the sword or the conversion). According to a contemporary expounder, Amr Abd al-Aziz: "the verse was revealed specifically about Christians and Jews. Idolaters and similar godless and permissive people have to be compelled to adopt Islam, since they cannot be accepted as dhimmis and do not deserve any consideration because of their godlessness, stupidity, error and foolishness" (apud Crone, 2009).

- It was descriptive, according to the mu'tazilites (an interpretation later accepted by other groups): there was no compulsion for God, neither for Muslims nor for others. But men, for various reasons, could force the practice (and not, by definition, belief). This served both for the good of the community as a whole (the maintenance of an Islamic public order) and for the descendants of the "convert".

It was in the 19th-20th centuries that interpretations of this passage took a new turn, to accommodate in a certain way the post-Enlightenment Western perspective. Indeed, a similar mutation has occurred with the concept of jihad in the XIX century, according to Cook (2015).

However, in many traditionalist clerical milieux there still persists a variation of those historical interpretations. Crone sums up the theological debate: "everybody is agreed that Islam goes in for religious freedom, but not on what it means, except that Christians and Jews shouldn't be forced to convert. Everything else is unclear" (CRONE, 2009). What are then, the features of this freedom given to the dhimmis - Jews, Christians and possibly others -, whose religions can be tolerated)?

The Muslim attitude toward the so-called "Peoples of the Book" (Ahl 
al-Kitab) or "Protected People" (Ahl al-Dhimma) can be briefly summarized as ambiguous and supercilious. As noted by Ussama Makdisi (BAER; MAKDISI; SHRYOCK, 2009), tolerance does not mean equality. There was no policy of forced conversion for dhimmis, but one of subordination, especially in the public space. There was an expectation of a game between visibility and invisibility, autonomy and submission, freedom and coercion. The visibility of Jews and Christians should not be ostentatious, and could frequently be discriminatory (such as sumptuary laws). There was autonomy in the sense that the religious communities were allowed to follow their own religious laws, chiefly in the domain of personal status - yet this autonomy was also given to the Muslim communities (accounting for the abysmal gap between the State and society in the pre-modern period). In other words, for most of the time the population was left to their own devices.

$$
\begin{aligned}
& \text { According to Sharkey: } \ldots \ldots \ldots \ldots \ldots \ldots \ldots \ldots \ldots \ldots \ldots \ldots \ldots \ldots \ldots \ldots \ldots \ldots \ldots \ldots \ldots \ldots \ldots \ldots \\
& \text { Muslim leaders }[\ldots] \text { combined tolerance on the one hand, with a scorn for and } \\
& \text { persistent mild denigration of Christian beliefs on the other. This treatment, } \\
& \text { combined subsequently with various inducements (such as tax breaks and profes- } \\
& \text { sional opportunities), made conversion to Islam quite attractive for the Christian } \\
& \text { people placed under Muslim rule (SHARKEY, 2017, p. 38). }
\end{aligned}
$$

In this context, a central feature of the Ottoman system of government came into play: the assimilation and integration of conquered peoples, which composed an empire that spanned three continents, including the central lands of the Islamic world.

Ethnic and religious diversity in the 0ttoman Empire

Although the empire's bureaucracy assimilated its various ethnic components into a centralized Islamic-dynastic unity (the elite identifying themselves as Ottoman, not Turkish), based on a religious premise (the officially recognized religious communities, the millets), there was a split between ethnicity and religion in the various regions of the empire:

- Albanians could be Muslims (Sunnis, Bektashis), Orthodox or Catholics; [FOOTNOTE: The Bektashis were a sufi order. "Bektāšīs believed that formal worship was incumbent only

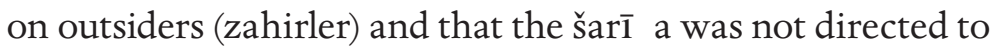
individuals, having rather the cosmic function of maintaining order in the universe." (ALGAR, 1989)]

- Bulgarians, Orthodox or Muslims (pomaks);

- Greeks and Bosnians could be orthodox or Muslim;

- Turks could be Sunnis, Shias or Sufis (or variations and syncretism between these divisions)

- There were Jews who converted to Islam (the Dönmeh);

- Kurds could be Sunnis or Yezidis;

- Jews could be Arabs (Mizrahim), Sephardic (Ladino speakers, with a strong presence in Saloniki);

- There were orthodox "Greeks" (karamanlides) who wrote Ottoman Turkish in the Greek alphabet; 
- Arabs could be Sunnis, Shiites, Druze, Alawites, Orthodox, Catholics or Protestants...

The question is: who was the "Ottoman"? Was he Sadık Pasha, né Michael Izador Czaykowski, a Polish count who entered the Ottoman service in the 1830s, converted to Islam, and went on to pursue a distinguished military career? Or was he Amir Bashir Shihab, a Christian Lebanese who in the early 1820s "practiced Sunni Islam in public and Christianity in private, [and] allowed a Maronite priest to take charge of his spiritual life"? Or was he the Druze and Alewi chieftain in the Lebanese mountains who practiced taqiya (dissimulation), while "by centuries old tradition" taking his disputes to Ottoman Sunni Shariat courts? Or was he Grand Vizier Mehmed Sokollu (Sokolovič, 1505-1579), whose brother, the monk Makarios, ruled as the Patriarch of the Serbian Church at Peč? (DERINGIL, 2000, p. 550).

The very social fabric of Ottoman society, and even more of its elite, was originally a "melting pot", due to the intensive practice of having concubine slaves and the devshirme. According to Peirce, after an initial period in which there were marriages to Anatolian potentate daughters (the first two generations), no royal consort was Muslim or Turkish (PEIRCE, 1993, p. 37). The attitude towards the conversion of non-Muslims to Islam that seems to have predominated was essentially pragmatic, especially when it came to skilled labor: in Deringil's expression, "go through the motions and you are accepted" (DERINGIL, 2000).

The two institutions that dealt with this internal and external plurality were, respectively, the millet system and capitulations. Regarding millets, although they were only formally characterized in the nineteenth century (BRAUDE, 1982), the traditional Islamic governance policy of the dhimmis provided more latitude than the European policy of cuius regio, eius religio:

[W] hereas the Ottoman Empire was strict in its condition of political allegiance but accommodated a religious allegiance out of state, the European countries conflated the two and deemed any religion other than the state religion a potential source of disloyalty or treason (BERGER, 2014, p. 161).

Yet one could also inversely argue that, once one excludes a religious group out of the legitimate participants of the political game, that group is relegated to a dichotomous and subordinate position consisting either of asserting an unwavering allegiance out of existential fear or engaging in open rebellion. Either way, the French Revolution and subsequent policies that extended popular sovereignty would eventually make this point moot.

This structure of recognition and autonomy, separation and subordination of religious communities would be affected by two contradictory forces. The modernization brought about by the Tanzimat is inherently unstable: on the one hand, there was a push for integration with a certain legal equality between Muslim and non-Muslim subjects; on the other hand, autonomy, privileges and socio-economic development were linked to Europe (eventually leading to nationalism and independence). We have chosen here to expound two cases that epitomize this tension: the official recognition of the Greek-Catholic (Melkite) millet and the civil war in Mount Lebanon in 1860. 
6. Whose beginnings we can attribute to the Counter-Reformation: the establishment of Eastern colleges in Rome in the 16th century and of the Sacra Congregatio de Propaganda Fide in 1622. (Ruthenians / Ukrainians had previously separated from the Orthodox in the Union of Brze区区 in 1595-96, with subsequent unions in 1646 in Uzhhorod / Ungvár and in 1664 in Mukachevo).
The establishment of the Melkite millet in 1848

The Greek Catholic or Melkite Church is a Byzantine rite Church that separated from the Greek Orthodox and united with the Roman Catholic Church in 1724. Most of them dwelt in cities, which were the base of their bishoprics, and were Arabic speakers. Contrary to an "ethnic" theory for the split with the Orthodox, "the patriarchs and bishops until 1724 were mostly of Arab origin" (WALBINER, 2003, p. 11).

The union with Rome is the result of a long process, in fits and starts, enmeshed with local and international rivalries. ${ }^{6}$ Already in 1684 Euthymius al-Șaifi, metropolitan of Tyre and Sidon, united with Rome. His independence from the Orthodox patriarch of Antioch, who resides in Damascus, was supported by local potentates and French merchants (WALBINER, 2003, p. 11). Institutional build up and support by foreign powers, missionaries, and local and international merchants was fundamental to strengthen the pro-Catholic cause among Orthodox communities. They made the mountains of Lebanon their first strongholds: the Monastery of the Savior (Dayr al-Mukhallis), whose construction started in 1708, and the Monastery of St. John, in Shuwayr (WALBINER, 2003, p. 11). In the period up to 1724 , several metropolitans sent their professions of faith to Rome, and the patriarchs had an ambiguous position toward this trend. The crucial step in official communion with Latin Christendom came from the important city of Aleppo, in present northwest Syria.

The presence of Western Catholic missions and socio-economic factors made the majority of the population of the city of Aleppo in the early seventeenth century pro-Catholic. The election of the first "officially" Catholic patriarch took place in 1724, when the Damascenes elected Seraphim Tânâs, named patriarch under the name of Cyril VI. However, when the Sublime Porte confirmed the election of the monk Sylvester (a Greek) to the patriarchy, Cyril fled to Shuwayr, where he was confirmed patriarch by the pope in 1729 (MASTERS, 2004, p. 89). Sylvester's policy alienated Aleppo's population (who had apparently supported his nomination because they had not been consulted on Cyril's election in Damascus, according to Masters). Catholics in the city, in a petition supported by Muslims, claimed that Sylvestros' policy had caused many Christians to leave the city, thus causing economic harm a threat that would be repeated several times (MASTERS, 2004, p. 91).

The Catholics struggled for institutional support in Aleppo. The Metropolitan of Aleppo, Maximos al-Hakim, declared himself a Catholic and was appointed by the pope in 1730. Maximos got approval from Istanbul through the "gift" of 45 bags of silver coins. After several twists and turns, with both communities appealing to local judges and in Istanbul, and after an exile in Lebanon, Maximos returned to Aleppo in 1734. The question remains: why did conversion to Catholicism occur mainly in two major cities (Istanbul, with the Armenians, and Aleppo)? According to Masters, the two main hypotheses put forward - the presence of European traders (and also missionaries) and the desire to affirm an ethnic (Arab) identity - are not satisfactory. These two hypotheses cannot account for several anomalies: the city of Izmir, which had a much stronger presence of European traders, and Damascus, a quintessentially Arab city, did not 
embrace the Catholic cause so fervently. Furthermore, Armenians and Jacobites? did not have a strong "linguistic gap" between the liturgical language and the vernacular. Thus, something else must be at play.

According to Masters, a plausible explanation is that "Catholicism met the political, cultural, and spiritual needs of an emergent Christian mercantile bourgeoisie and they embraced it with enthusiasm" (MASTERS, 2004, p. 96). One aspect of this change is reflected in the creation of lay brotherhoods (HEYBERGER, 1996). Another crucial factor was the maintenance of Byzantine traditions (married clergy, fermented bread, holidays, etc.). A psychological transformation, according to Masters, was also at stake:

They were protected behind that all-important façade of tradition, while committing themselves to a place in a new economic and political world-order, increasingly dominated by the West. (MASTERS, 2004, p. 97)

Figure 1 - Melkites in Lebanon and Syria - Historical and Contemporary Presence

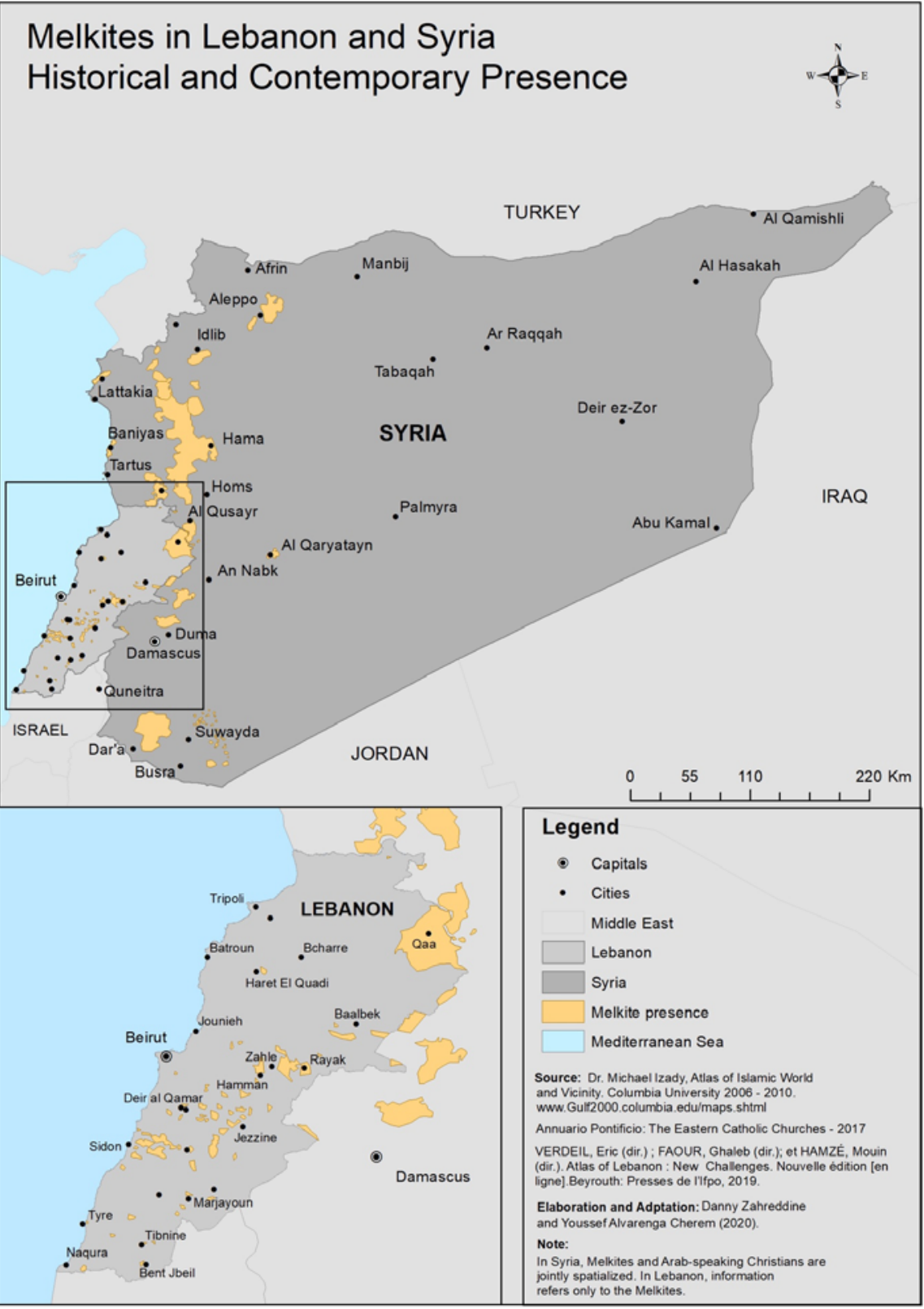

7. The Jacobite or Syriac Orthodox Church is Monophysite (non-Chalcedonian) Christian Church. As the Maronites, they follow the West Syriac Antiochene rite, but with extensive use of Syriac as a liturgical language. The Syriac Catholic Church emerged between the late seventeenth and early eighteenth centuries and has around 150,00 faithful. Its patriarch resides in Beirut. The Syriac Orthodox Church has more than 2 million followers mainly in Syria, India (Malankara Syrian Orthodox Church), and elsewhere in the diaspora. There is also a sizable recently converted community in Guatemala. 
8. The Druze religion is an esoteric offshoot of Isma'ili Shiism. The Druze people are concentrated in the Levant (present-day Israel, Syria, and Lebanon). The Maronites are Catholic a community that has been in union with Rome since the 13th century. They follow the Syriac-Antiochene rite. Originated from a monastic community in near the Orontes river, present-day Syria, the sought refuge from other Christian groups, and later from Moslems, in Mount Lebanon. They progressively adopted the Arabic language for daily usage and literature both sacred and profane, and also for most of the liturgy.

9. Hobsbawm defines protonationalism as "Certain variants of feelings of collective belonging which already existed and which [...] could fit in with modern states and nations" (HOBSBAWM, 2012, p. 46)
It is also worth noting the allure of Catholicism to women, who had more freedom and agency in the face of the stricter restrictions of the Orthodox Church. Missionaries valued more the role of women, who began to become literate or choose a life of celibacy (Orthodox monasteries were common to men and women), culminating in their insertion in the capitalist economy at the end of the nineteenth century and in public life (although not in politics) around the same time. The missions were also influential for the Arabic "renaissance" (Nahda) in the late 19th century, with figures such as the Melkite Nasif al-Yaziji (1800-71), the Maronite/ Protestant Butrus al-Bustani (1819-83), who participated in the translation of the Bible into Arabic, and the writer Faris/Ahmad Shidyaq (Maronite, and later Anglican and finally Muslim).

It would be the case, then, of "elective affinities" and a "hybrid" worldview, although not necessarily political for the time being. The identity was strengthened by the "persecutions" at the hands of the Orthodox, by a hierarchy that could be perpetuated (note Euthymius's effort to appoint bishops), the refuge granted on Mount Lebanon by the local potentates (Druze) and the Maronites, ${ }^{8}$ and the capacity to use economic and political power (WALBINER, 2003, p. 14). In this regard, its presence in Egypt is illustrative. According to Crecelius:

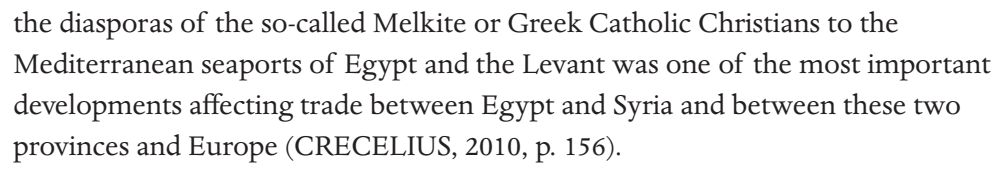
developments affecting trade between Egypt and Syria and between these two provinces and Europe (CRECELIUS, 2010, p. 156).

Establishing themselves with great success in the Levant, the Melkites supplanted Europeans in commerce at the end of the eighteenth century. They acted as agents for the governor of Acre, Ahmad Jazzar Pasha, in the lucrative cotton trade, defending his monopoly. After the 1770s, the Mamluk shaykh al-balad in Egypt, Ali Bey al-Kabir, transferred Egyptian customs from Jews to the Melkites, who then controlled customs at all ports except Suez. Given these connections, they profited greatly from import and export monopolies (CRECELIUS, 2010, p. 158).

Issawi (1982, p. 261) noted that

$$
\begin{aligned}
& \text { foreign or minority groups played a very important role as intermediaries } \\
& \text { between Western capital and the local population: Chinese in Southeast Asia, } \\
& \text { Indians in Burma and East Africa, Lebanese in West Africa and so on (...) The } \\
& \text { function of the millets was essentially that of middlemen between the Muslim } \\
& \text { masses and the forces that were transforming them, i.e., European capital and } \\
& \text { enterprise and modernizing Middle Eastern governments. }
\end{aligned}
$$

The historian Bruce Masters affirms that the need to institutionalize its distinct status that lead to the official recognition of the Melkite millet in 1848 was more a result of what could be characterized as an "identity policy" - borrowing Hobsbawm's term: "protonationalism" - than a question of dogma (MASTERS, 2010). ${ }^{9}$ The Melkites, although primarily of Arabic demanded a millet separate from the one that would cover all Catholics (the Armenian Catholic millet had been recognized in 1830). However, Greek Catholics did not identify themselves with a 
"national Church" (like the Orthodox Bulgarian Church, recognized as a millet in 1870). The argument used by the Melkites was that they were simply the Byzantine Christians (Rûm) of Syria (Suriya, not Bilâd alShâm), and that they had never deviated from loyalty to either the Pope or the Sultan (as the Orthodox Greeks had). ${ }^{10}$

In the Ottoman Empire in the nineteenth century, Christians and, to a lesser degree, Jews, thrived not only on commerce and industry but also in the liberal professions, forming a large portion of the urban middle class, public servants, and foreign companies. In commerce, industry, liberal professions, and the bureaucracy, they naturally amassed a great deal of wealth - though, as Issawi noted, "the vast majority remained in the ranks of the petty bourgeoisie or lower". (ISSAWI, 1982, p. 262). This situation of relative prosperity and privileged status (as perceived by the Muslim population) did not change until the nationalist upheavals of the middle 20th century.

Figure 2 - Minority shares in the import-export sectors of Trabzon (1884) and Beirut (1848).

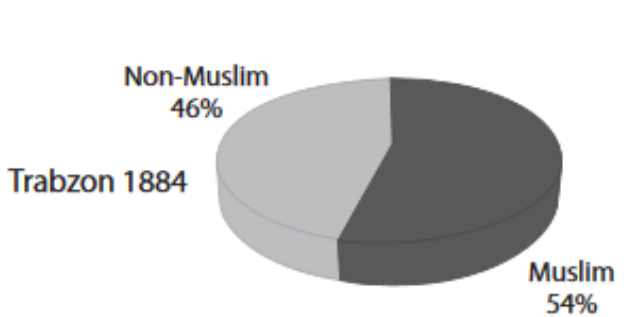

Population

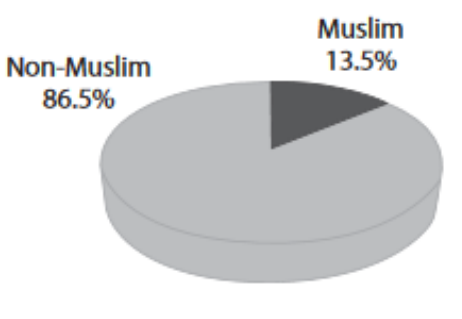

Importers and exporters

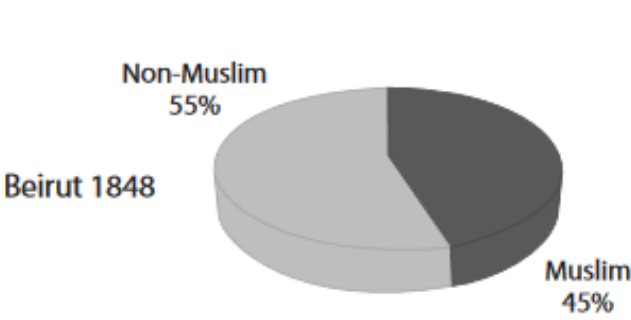

Population

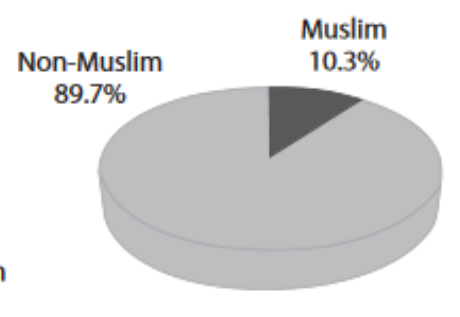

Importers and exporters
Source: Kuran, 2011, p. 192.

From the mid-nineteenth century onwards, most importers and exporters in major cities of the Empire - Alexandria, Baghdad, Aleppo, Beirut, Izmir, Trebzon, and even Istanbul - were held in the hands of either foreigners or local minorities (Figures 1 and 2). In this, the local Christian minorities in Aleppo were no exception. "In Aleppo, Muslims maintained a major presence in commerce, but all the wealthiest merchants were Christian." (KURAN, 2011, p. 193.) Therefore, foreign commercial presence alone does not explain such a prolonged, winding shift in religious allegiance as the process Melkite-Orthodox divide.
10. The policy of the orthodox millet, centered on the figure of the ecumenical patriarch of Constantinople, was founded on the latter's claim of authority over all orthodox subjects in the empire. Paradoxically, Ottoman unification offered the possibility of claiming more direct control of the Orthodox by the patriarch of Constantinople, especially after the Mamluks (Jerusalem was very important to be conceded autonomy to, but the other headquarters, Alexandria and Antioch, elected their own leaders). The quest to strengthen the ecumenical patriarch's authority was also linked to Catholic missionaries, active at least since the mid-seventeenth century. The two millets recognized in the 18th century - Armenian and Orthodox - had their own liturgical languages, and Christians who were neither Armenian nor Orthodox were under the "political" jurisdiction of the Armenian patriarch. 
11. "By the end of the eighteenth century, when the Ottoman population was around 30 million, the Austrian alone were protecting 200,000 Ottoman subjects (...) By 1808, Russia had extended protection to 120,000 people, mostly Greeks. In 1882, "foreign subjects" accounted for 112,000 of the 237,000 residents of Galata, Istanbul's leading commercial district; most were natives. In 1897, half of all the Jews in Egypt were foreign nationals" (KURAN, 2011, p. 201).
Figure 3 - Muslim and minority shares of major Ottoman traders, 1912.

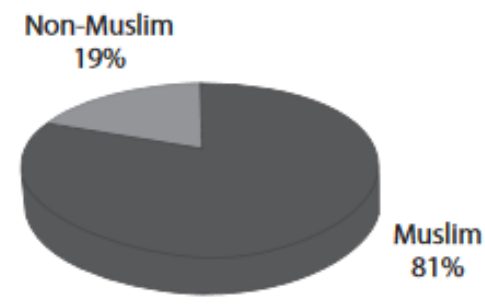

Population

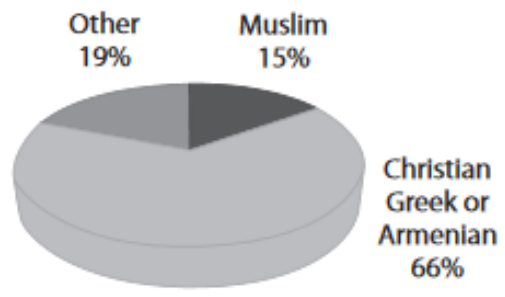

Major local traders
Source: Kuran, 2011, p. 193.

This peculiar position was fostered, besides the reforms, by foreign protection and foreign education. "As of the mid-nineteenth century, in Aleppo alone more than 1,500 non-Muslim Ottomans were engaged in international trade under a foreign government's protection." (KURAN, 2011, p. 201). Many local Christians were favored by the so-called system of capitulations, whereby European subjects and their local protégés were granted exemption from the jizyah impositions (MASTERS, 2009) and other taxes, payed the same amount of customs duties as the Muslims (3\%, compared to $5 \%$ paid by dhimmis) and legal protection through a legal concession named berat (MASTERS, 2004, p. 74).

A notable development was the increase in power of local Consuls, who intervened on behalf of their nationals and local allies. Bruce Masters also adds that "Many of the critics of the protégé system also point to its wholesale abuse for either monetary or political gain by the European consuls who obtained berats far in excess of the numbers to which they were entitled." (MASTERS, 2004, p. 78). ${ }^{11}$

The Christians' socio-economic status was, through the reforms carried out since the period of Egyptian occupation, raised by Westernizing reforms, increasing juridical equality, and European protection, being a source of resentment for the Muslim majority (DERINGIL, 2015, p. 38; HADDAD, 2015). The Tanzimat reforms were put to test, surprisingly, not in the central or more prosperous European domains of the empire, but in the events in Mount Lebanon and Damascus.

The massacres of 1860 in Mount Lebanon and Damascus

In the first centuries of Ottoman dominion, Mount Lebanon and its environs were able to secure a certain autonomy vis-à-vis the Sublime Porte. The Maronites and the Druze were the core constituents of an autonomous emirate in Mount Lebanon from the $16^{\text {th }}$ century onwards, particularly after the rule of Emir Fakhr el-Din al Maan (ruled 1591-1635).

France had developed ancient political ties with the Maronites and claimed to be protectors of the Catholics of the Ottoman Empire, whereas the Maronites regarded France as their allies and supporters in a hostile environment, perched high in their strongholds in Mount Lebanon. Maronite identity was, then, shaped throughout the centuries 
largely through the relationship with the Catholic Church and France (HEYBERGER, 2018; ARSAN, 2016) They would also be instrumental in the crystallization of a Christian-centered, Maronite based nationalism (HAKIM, 2013; KAUFMAN, 2014) and Lebanese independence (ARSAN, 2015; FIRRO, 2002)

Religious missions, such as the Franciscans and Dominicans, and later the Jesuits, helped to keep the relationship with Rome constant and deepened a sense of distinct Maronite identity. In addition, the creation of the Maronite College in Rome in 1584 for Maronite seminarians was also of great importance.

The institutionalization of what is known as sectarianism or communitarianism in the Lebanese political and social context emerged in the nineteenth century, as a result of the confluence of regional and international factors. As Usama Makdisi writes, "it is imperative to dispel any illusion that sectarianism is simply or exclusively a native malignancy or a foreign conspiracy" (MAKDISI, 2000, p. 2). Sectarianism, as conceptualized by Makdisi, is "refers to the deployment of religious heritage as a primary marker of modern political identity" (MAKDISI, 2000, p. 7). Here we follow Makdisi's lead, situating the fateful events in the context of the Ottoman modernizing reforms.

Until the middle of the nineteenth century, the social structure in Lebanon could be described as a local variant of the Ottoman pattern:

- Muslims and dhimmis (mostly commoners, with a large peasant base);

- The "nobles" (manâsib) and the "commoners" ('amma)

- Local potentates and central power

- Muqata jis (tax farmers, holders of an iqtấa or iltizâm)

The social division was expressed by a feudal stratum (mostly Druze) and a mainly peasant base (most Christians). The nobles lived by extracting income, through iqtâ $\hat{a}^{\prime}$ or by renting land. There were often conflicts among the nobility or with central power (see Fakhr el-Din in the seventeenth century and Bashir Shihab II in the $19^{\text {th }}$ ). "Local rulers (...) generally controlled a port, trade route or vital produce (coffee, cotton, silk, etc.)" (TRABOULSI, 2012, p. 4).

Revolts concerning taxation were common. Emir Bashir Shihab II (1788-1840) (the Sunni dynasty of Shihab had succeeded that of the Ma 'an in the seventeenth century) allied with Druze leader Bashir Jumblat against the tax revolt in 1820-21. The alliance ends in 1825, when Shihab tries to extend his power at the expense of the Druze lords. Jumblat opposes Shihab (now openly declared a Christian) and gets help from the governor (wâli) of Damascus. Shihab, on the other hand, already had as an ally the governor of Acre, who managed to attract Jumblat to his city and behead him. As a result, the Druze lords were stripped of their fiefdoms, only two of which remaining in their hands. These lands were distributed among the Shihab family, who got closer to the Maronite Church (TRABOULSI, 2012, p. 11).

Bashir Shihab II helped with the invasion and Egyptian control of the Levant, under the command of Ibrahim Pasha, son of Muhammad Ali, governor of Egypt. The policies implemented in Egypt's government 
were reproduced in Syria. Industry and foreign trade were stimulated. The State had a monopoly on silk, and Beirut being established as a mandatory entrepôt for the product. Ibrahim Pasha's government was not popular with the local population, due to high taxes, forced labor and military service. To fight a Druze revolt in Hawrân, which had spread to Beqaa and Wadi al-Taym, Ibrahim had armed the Christians against the Druze and others. The catalyst for Christians to join the revolt was the decision to retake their weapons. In 1840, Maronites, Druze, Shiites and Sunnis started a revolt against Bashir. The revolt was mainly led by popular leaders (sheykh shabâb) (TRABOULSI, 2012, p. 13).

With European support (the British feared the Ottoman weakening vis-à-vis Russia), Ibrahim is defeated and retreats to Acre. The new emir, Bashir Milhim Qasim (Bashir III), took over with foreign support. Yet the Maronite Church wanted the continuation of the emirate of the Shihab, the Druze wanted instead a return to the previous status quo (HARRIS, 2014, p. 140). The Ottomans and the British supported the return of properties to Druze (TRABOULSI, 2012, p. 14), while the Maronites and Melkites of the Shuf and Jezzin did not want the Druze to return to further increase the tax, on top of the tax they were already paying (HARRIS, 2014, p. 140).

At that time, there was a social, political and economic disjunction between the Christians and the Druze:

a Druze bloc, primarily tribal, in which the tributary and military function dominated, and a Christian bloc, with a wide peasant and artisan base and commercial/financial ramifications (TRABOULSI, 2012, p. 15).

If in the north Christian manâsib extracted income from Christian peasants, in the south, Druze manâsib dominated Christian peasants. Druze commoners paid little tax, if at all. As Traboulsi shows, Christians benefited much more from the expansion of regional and international trade and industrial and artisanal production in cities on commercial routes - Deyr al-Qamar, Zahlehh, Beirut (TRABOULSI, 2012).

After the fall of Bashir III, the Druze, supported by the British, demanded a Muslim governor, while the Maronites defended a Christian governor. Although the Druze theoretically demanded a Muslim governor, they did not welcome Governor Ömer Pasha, a Muslim Croat, sent by Istanbul to administer Mount Lebanon directly from Deyr al-Qamar.

Austrian Chancellor Metternich proposed a division of the north, with a Christian governor, and the south, with a Druze governor - the system known as Qaimaqamatayn. Neither party accepted the agreement well: the Maronite Church demanded that southern Christians $(60 \%$ of the population) be under the authority of the northern qaimaqam, while the Druze demanded complete control over Mount Lebanon. 


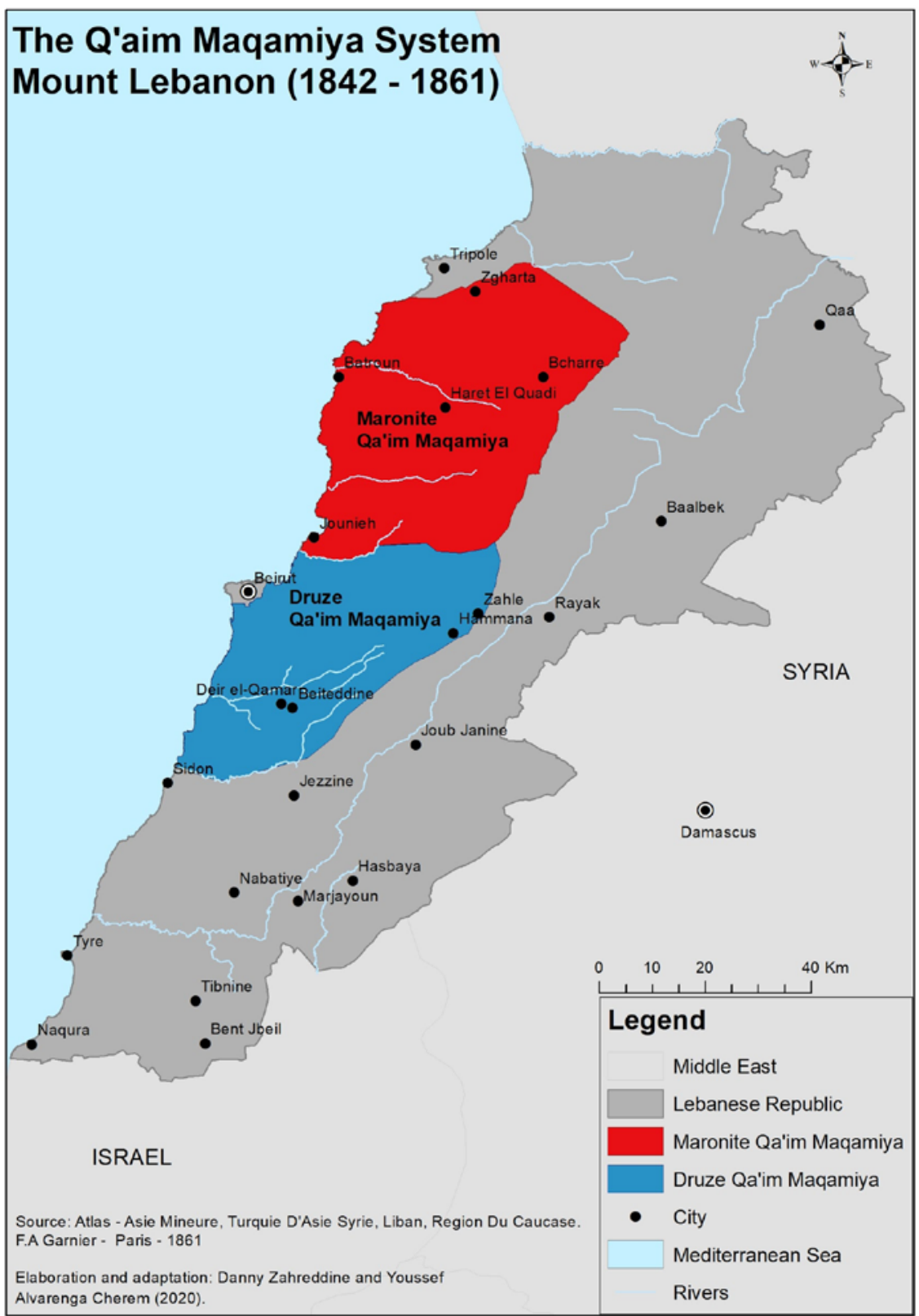

A series of conflicts emerged in this context:

- intra-elite conflicts: in the South, the Jumblats did not accept the appointment of Amin Arslan as qaimaqam; in the North, the Khazins opposed the Abi Lama'as.

- the muqata'jis resisted the implementation of the 1858 Ottoman land ownership law;

- conflicts between the returning Druze and commoners

- cities freed themselves from the control of the muqata'jis Amchit from the Khazin; Ghazir, from Hubaysh, Deyr al-Qamar, from the Druze Abu Nakads, and Zahlehh from the Abi Lama'as. Zahleh also managed to connect with the wilaya of Beirut, and afterwards of Sidon, escaping the administrative sphere of Mount Lebanon. 
12. The Lebanese have a tendency of euphemistically calling their wars and conflicts mere "events" (al-ahdath), such as in the last Civil War (1975-1990)
13. An eyewitness to the massacre was the American vice-consul in Damascus, Mikhail Mishaqa, who wrote a history of the conflict. Mishaqa was a Greek Catholic who had business in Egypt, Galilee, Syria, and Lebanon and converted to Protestantism by American missionaries (ROGAN, 2004)
The revolt against the rule of the muqata jis broke out in late 1858 under the leadership of Tanius Shahin (1815-95), and controlled the Kesrawân region for two years. A directly elected council had Shahin as president. According to Traboulsi, they were pioneers in implementing the provisions of Tanzimat. They railed against excessive or additional taxes, demanded the establishment of a court to settle conflicts between sheiks and the people, called for an end to the sheikhs' political and legal privileges, political participation (appointment of a governor), and the abolition of feudal mores - forced labor, "gifts" for sheiks (coffee, tobacco, sugar, soap), distinctive clothing and kissing the sheikhs' hands. Two tendencies emerged in the revolt: the "bourgeois", according to which the criterion of distinction should be property, and the peasant, who demanded equality with the Christian sheikhs and with the Muslim majority of the Empire. The Maronite Church steered a middle path between the peasants and the conservative upper strata of the Maronite clergy and society.

The so-called "events of $1860^{\prime \prime 12}$ can be interpreted under the prism of the social and political struggles in the northern districts and against the backdrop of the wider measures of the Tanzimat:

$$
\begin{aligned}
& \text { The fighting in the southern part of Mount Lebanon was initiated by the Druze } \\
& \text { leadership as a preemptive measure to ward off the possible repercussions of } \\
& \text { the Kisrawan revolt but, more importantly, to overcome the social and political } \\
& \text { agitation of their 'own' Christian commoners (TRABOULSI, 2012, p. 33). }
\end{aligned}
$$

The city of Deir al-Qamar fell, resulting in an estimated massacre of 900 to 2,000 Christians. The Druze claim that there were about 4,000 weapons in the city, but, according to Christian reports, the weapons had already been collected by Turkish authorities, from which protection was expected. The Druze also sacked the Orthodox villages of Hasbaya (where 17 Sunni Shihab sheikhs were killed) and Rashaya. Zahleh was pillaged, having received no help from the Maronites in the Mountain. Both communities took the opportunity to expel Shiites from their respective territories (TRABOULSI, 2012, p. 35). In the end, around 11,000 persons lost their lives in the Lebanon conflict (FAWAZ, 1994, p. 226).

Sectarian conflict spilled over to Damascus and took a different turn. In 1860, after simmering tensions, the mob went berserk, going after the Christians, especially in the quarter of Bab Touma, which was virtually razed to the ground. The violence lasted for days. There was killing, looting, burning, rape and abduction of women and children. The Turkish authorities were negligent; the Moslem religious leaders, the ulama, abstained; the police and irregular troops actively participated in the riots. The rampage soon turned to Westerners: "Foreign consulates were an early target, a measure of Muslim belief in foreign plots and resentment against the humiliations inflicted on them by the Western powers." (FAWAZ, 1994, p. 89). ${ }^{13}$ According to estimates 12,000 people perished in Damascus in a week (FAWAZ, 1994, p. 226; SALIBI, 1988, p. 138). Many were saved by the Algerian emir Abd al-Qadir, a resident of Damascus at the time. The number of displaced, injured, maimed, or abducted, or of those who lost their property and livelihood, is impossible to ascertain.

The sense of upended social order explains, according to Masters (2004), the series of popular riots aimed at Christians: Aleppo (1850), Mo- 
sul (1854), Nablus (1856), Jeddah (1858), Egypt (1882) (MASTERS, 2004; POLLEY, 2020; SHARKEY, 2017, p. 146). Fawaz (1994, p. 99-100) argues that economic resentment was at play both in Aleppo and in Damascus. On the other hand, Grehan contends that "the origins of these disturbances lay not in the penetration of the modern world economy but in the extended political crisis that shook the Ottoman Empire during the late eighteenth and early nineteenth centuries.” (GREHAN, 2015, p. 491.)

The Damascus affair also illustrates the opposition to the Tanzimat. Spurred by economic resentment and socio-political grievances, the crowd turned against the most visible signs of what they perceived as their humiliation and gave vent to their anger. Moslems in Damascus celebrated the fall of Zahleh, the Melkite stronghold in the Beqaa and their rivals in grain and livestock trade, at the hands of the Druze (FAWAZ, 1994, p. 81). Whereas the strife in Mount Lebanon pitted Druze against Maronite, in Damascus the mob attacked mainly Melkites, who had cultural and commercial ties with foreigners, especially the French merchants. Significantly, the mobs spared the Jews and poor Christian neighborhoods (SHARKEY, 2017, p. 215).

Pressure from the massacres on Mount Lebanon and Damascus prompted Istanbul to send Foreign Minister Fuad Pasha to Beirut, where he arrested the governor, Khurshid Pasha and several Druze leaders, including Said Jumblat. In Damascus, the reaction was brutal. Fuad Pasha arrested and executed Governor Ahmad Pasha, officers, soldiers and officials (TRABOULSI, 2012, p. 35).

\begin{abstract}
The authorities arrested hundreds of Muslim men, and publicly executed scores of them. Records identified the executed by their professions, thereby offering some insight into class origins: they included lemonade sellers, barbers, bead traders, carpenters, and other assorted shopkeepers and artisans. On one day in August 1860 alone, Ottoman authorities executed 167 men as their families and other members of the public looked on; they then suspended the corpses of 57 of them in bazaars and streets, and on gate-posts, as grisly memorials of the punishment (SHARKEY, 2017, p. 151-152).
\end{abstract}

As foreign pressure mounted, a French expeditionary force of 6,000 men was sent to Beirut. The government of Mount Lebanon was structured through the 1860 Reglement Organique, as an autonomous area governed by a non-Lebanese Christian appointed by the Sublime Porte.

Several authors tended to view these events in 1860 either as an outbreak of atavism, or as a plot by foreign powers (Turkish historiography) or the Ottoman Empire (Arab historiography) (MAKDISI, 2000, p. 5-6). Fuad Pasha himself described the events as "a very old thing", adopting a paternalistic and authoritarian imperial language, consistent with the ongoing Tanzimat reforms (MAKDISI, 2002). This period, between the fall of Bashir Shihab II and the establishment of Mutasarrifiyah - "long peace" from 1860 to 1914 (AKARLI, 1993) - can be contextualized as a period of transition in the context wider range of reforms from the Ottoman Empire in the second half of the nineteenth century. As Makdisi states:

Sectarianism emerged as a practice when Maronite and Druze elites, Europeans and Ottomans struggled to define an equitable relationship of the Druze and Maronite "tribes" and "nations" to a modernizing Ottoman state (MAKDISI, 2000, p. 6). 
14. This type of identification is the opposite of social contexts in which the identification of an individual is a social marker that, in the end, does not need to be linked to faith (the case of the communist Shiite, the "atheist Protestant" or "secular Jew") , but in a "civic religion" (as in the Roman Empire), merely social or nominal - see the charge that "nominal Catholics" are not "true" Christians, or the more extreme charge of evangelicals that "traditional" Christians are only nominal Christians, and the accusation by Salafists / Wahhabis that all other Muslims are

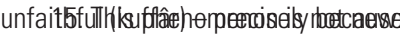

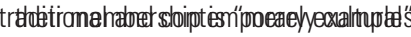

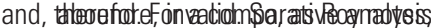

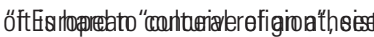

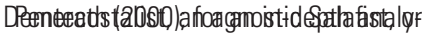

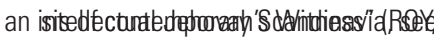
Zuckerra目年42008).
The intermingling of foreign and domestic politics, together with the redefinition of social and political roles and a deepening of economic insertion, were crucial aspects in the definition of Lebanon's political structure after the First World War under the French mandate.

Conclusion

Both cases dealt with here resulted from changes in the social, economic and geopolitical context in the Levant in the $19^{\text {th }}$ century. The crucial milestones of these changes were:

a) the European political, cultural, economic and religious presence;

b) the integration of Christian communities and individuals in the discourse and a worldview of modernity and the recognition and strengthening of their religious identity, and

c) the Ottoman reform policy, both at the imperial and local levels.

These factors concurred both to the gruesome events in Mount Lebanon and Damascus in 1860 and to the creation of an autonomous region in Mount Lebanon, leading to the formation of the Lebanese State in the 20th century. Foreign missions, schools, trade, and diplomacy were instrumental in creating a new social, and subsequently political mindset among the Christian subjects of the Empire in the Middle East. Aleppo was the center of Catholic missions in the region, that the port cities of Tire, Beirut, Sidon and Acre had European consuls and commerce dominated by Christians (LONGVA, 2012). This presence was fundamental for the creation of Uniate churches from the eighteenth century onwards (the Chaldean union in Iraq had several setbacks and another dynamic). Until then, the only Catholics in the Middle East had been either Latin-rite (foreigners) or Maronite. The conflicts between 1840 and 1860, culminating in the massacres on Mount Lebanon and Damascus, served to reaffirm, under the aegis of international protection and intervention, the autonomy of Mount Lebanon in the context of Tanzimat, confirming a Maronite desire and serving as a basis, after the destruction of the Ottoman Empire, for the establishment of the State of Greater Lebanon under the French. Furthermore, ties with Europe, and specifically with France, fostered the development of non-Arab nationalism under Maronite hegemony (FIRRO, 2002; HAKIM, 2013; KAUFMAN, 2014). Western education, through missionaries or local agents, was a decisive aspect of this process, and at the beginning of the $20^{\text {th }}$ century, literacy was almost universal among Maronites, unlike other communities, Christian or not (LONGVA, 2012).

One must bear in mind that religion in the Ottoman Empire (and in many cases, in the contemporary Middle East) is quite different from a contemporary context in which individuals are shaken and sometimes uprooted from an assigned social belonging and urged to actively identify with one cult or faith available in the spiritual and social "market", sometimes dissolving these phenomena in a literally transnational and "cross-cultural" movement (ROY, 2014). ${ }^{14}$

In the Ottoman Empire, religion was a cultural and social marker that is often divorced from faith and practice. ${ }^{15}$ It is significant that Protestant missions in the Middle East failed to win many converts (MAKDISI, 
2011). As we have seen, in the Ottoman Empire, as well as in many contemporary situations, religious belonging is "a matter of fact". Conversion is the exception, not the norm. It is, therefore, perfectly possible for a Turk to remain a Muslim even though she drinks alcohol, does not pray and does not don the hijab, or that an Israeli remains a Jew even though he thinks, like the founders of the State of Israel, that the Bible is a national epic, closer to myth than historical reality - even though fundamentalists of all stripes would staunchly deny legitimacy to this "ecumenical" identities in the public space.

The challenge of maintaining the territorial integrity of an extensive political unit, characterized by a multireligious and multiethnic population, is faced by most Empires. They search for an elusive formula that would maintain social contentment and political stability, ensure constant tax collection and military conscription, and garner allegiance.

The Ottoman Empire was no different in this sense. For a long time, its political and economic structure made it a formidable contender for supremacy in the European stage. The rise of industrial capitalism, nationalism, and the modern, rational bureaucratic apparatus (in the Weberian sense) and military encroachment and cultural challenge instigated a vigorous response that transformed the structure of the Ottoman State. Even if ultimately the survival of the Ottoman Empire rested on the European balance of power, the Tanzimat gave it a new lease on life. Yet the paradoxes of Ottomanism as a new overarching political identity would not be unraveled until its utter dissolution during World War I and its tragic consequences for the Ottoman Middle East.

As noted, one of the main features of the Tanzimat reforms lay in law and the juridical status of non-Moslems, and the minorities were a central component of the institutional and economic modernization of the Empire and of its international relations. The military conflicts between the Empire and the great European powers shaped the course of nationalist movements in Eastern Europe and the Middle East (including episodes of ethnic cleansing and forced migrations), the sectarian conflicts in Lebanon and the Balkans, and ultimately played an essential role in the creation of Greater Lebanon in 1920. We hope that further studies of the intricate intermingling of religion and power in International Relations seriously and critically reconsider the crucial role of religions identities in the construction of the modern international states system.

References

AKARLI, Engin. The Long Peace: Ottoman Lebanon, 1861-1920. 1st edition. Berkeley: University of California Press, 1993.

ALGAR, Hamid. Bektāšīya. In: ENCLOPAEDIA Iranica. [S.l.: s.n.], 1989. Available at: http:// www.iranicaonline.org/articles/bektasiya. Accessed on: 01 sep. 2020.

ARSAN, Andrew. "There is, in the Heart of Asia, an Entirely French Population": France, Mount Lebanon, and the Workings of Affective Empire in the Mediterranean, c.1830-1919. In: LORCIN, Patricia; SHEPARD, Todd (eds.). French Mediterraneans: Transnational and Imperial Histories. Lincoln, NE: University of Nebraska Press, 2016. p. 76-100.

ARSAN, Andrew. The Patriarch, the Amir and the Patriots: Civilisation and self-determination at the Paris Peace Conference. In: Fraser, T. G. (ed.), The First World War and its Aftermath: The Shaping of the Middle East. London: Haus, 2015. p. 127-145. 
BAER, Marc; MAKDISI, Ussama; SHRYOCK, Andrew. Tolerance and Conversion in the Ottoman Empire: A Conversation. Comparative Studies in Society and History, v. 51, n. 4, p. 927-940, 2009. Available at: https://www.jstor.org/stable/40270367. Accessed on: 24 jun. 2019.

BERGER, Maurits. A Brief History of Islam in Europe - Thirteen Centuries of Creed, Conflict and Coexistence. Leiden: Leiden University Press, 2014.

BRAUDE, Benjamin. Foundation Myths of the Millet System. In: LEWIS, Bernard; BRAUDE, Benjamin (Ed.). Christians \& Jews in the Ottoman Empire: The Functioning of a Plural Society. New York: Holmes \& Meier Pub, 1982, v. 1, p. 69-88.

BRAUDE, Benjamin; LEWIS, Bernard; (Ed.). Christians \& Jews in the Ottoman Empire: The Functioning of a Plural Society. New York: Holmes \& Meier Pub, 1982, v. 1.

BUNTON, Martin; CLEVELAND, William L. A History of the Modern Middle East. 4th Ed. Boulder, CO: Westview Press, 2009.

COOK, David. Understanding Jihad. 2nd edition. Berkeley: UC Press, 2015.

CRECELIUS, Daniel. Damiette and Syrian-Egyptian Trade. In: SLUGLETT, Peter; WEBER, Stefan. Syria and Bilad al-Sham under Ottoman Rule. Leiden: Brill, 2010. p. 155-175.

CRONE, Patricia. No pressure, then: religious freedom in Islam. Open Democracy, nov. 2009. Available at: https://www.opendemocracy.net/en/no-compulsion-in-religion/. Accessed on: 01 sep. 2020.

DEMERATH, N. J. The Rise of 'Cultural Religion' in European Christianity: Learning from Poland, Northern Ireland, and Sweden. Social Compass, v. 47, n. 1, 2000, p. 127-139.

DERINGIL, Selim. “There Is No Compulsion in Religion”: On Conversion and Apostasy in the Late Ottoman Empire: 1839-1856. Comparative Studies in Society and History, v. 42, n. 3, p. 547-575, 2000. Available at: https://www.jstor.org/stable/2696645. Accessed on: 01 sep. /09/2020.

DERINGIL, Selim. The Land of Polite Fictions: The Tanzimat State and Mount Lebanon. In: DE CLERCK, Dima, EDDÉ, Carle; KAIDBEY, Naila; SLIM, Souad. (ed.) 1860, histoires et mémoires d'un conflit. Beyrouth: Presses de l’Ifpo, 2015, p. 33-47.

FAWAZ, Leila Tarazi. An Occasion for War: Civil Conflict in Lebanon and Damascus in 1860. Berkeley and Los Angeles: University of California Press, 1994.

FRIEDMANN, Yohanan. Tolerance and Coercion in Islam: Interfaith Relations in the Muslim Tradition. Cambridge: Cambridge University Press, 2003.

FINDLEY, Carter Vaughn. Turkey, Islam, Nationalism, and Modernity: A History. London: Yale University Press, 2010.

FINDLEY, Carter Vaughn. Bureaucratic Reform in the Ottoman Empire: The Sublime Porte, 1789-1922. Princeton: Princeton University Press, 2012[1980].

FIRRO, Kais. Inventing Lebanon: Nationalism and State under the Mandate. London: IB Tauris, 2002.

GODDARD, Hugh. A History of Christian-Muslim Relations. Edinburgh: Edinburgh University Press, 2000.

GREHAN, James. Imperial Crisis and Muslim-Christian Relations in Ottoman Syria and Palestine, c. 1770-1830. Journal of the Economic and Social History of the Orient, v. 58, n. 4, 2015, p. 490-531. Available at: https://doi.org/10.1163/15685209-12341381. Accessed on: 01 sep. 2020.

HADDAD. Mahmoud. From Muslim Privilege to Christian \& Foreign Privilege in Ottoman Syria. In: DE CLERCK, Dima, EDDÉ, Carle; KAIDBEY, Naila; SLIM, Souad. (ed.) 1860, histoires et mémoires d'un conflit. Beyrouth: Presses de l'Ifpo, 2015, p. 49-68.

HARRIS, William. Lebanon: a history, 600-2011. Oxford: Oxford University Press, 2014.

HEYBERGER, Bernard. La France et la protection des chrétiens maronites. Généalogie d'une représentation. Relations internationales, v. 173, n. 1, p. 13-30, 2018. Available at : https://doi. org/10.3917/ri.173.0013. Accessed on: 01 sep.2020.

HEYBERGER, Bernard. Un nouveau modèle de conscience individuelle et de comportement social. Parole de l'Orient: revue semestrielle des études syriaques et arabes chrétiennes, v. 21, p. 271-283, 1996.

HOBSBAWM, Eric J. Nations and nationalism since 1780: Programme, myth, reality. [S.l.]: Cambridge university press, 2012.

HAKIM, Carol. The Origins of the Lebanese National Idea. Berkeley: University of California Press, 2013. 
ISSAWI, Charles. The Transformation of the Economic Position of the Millets in the Nineteenth Century. In: LEWIS, Bernard; BRAUDE, Benjamin (Ed.). Christians \& Jews in the Ottoman Empire: The Functioning of a Plural Society. New York: Holmes \& Meier Pub, 1982. v. 1, p. 261-285.

KAUfMAN, Asher. Reviving Phoenicia: The Search for Identity in Lebanon. London: IB Tauris, 2014.

KARAMAN, K. Kivanc; PAMUK, Sevket, Ottoman state finances in European perspective, 1500-1914. Journal of Economic History, v. 70, n. 3, p. 593-629, 2010

KURAN, Timur. The Long Divergence: How Islamic Law Held Back the Middle East. Princeton: Princeton University Press, 2011.

LEVY, Avigdor. Military Reform and the Problem of Centralization in the Ottoman Empire in the Eighteenth Century. Middle Eastern Studies, v. 18, n. 3, p. 227-249, 1982.

LITTLE, Donald P. Coptic Conversion to Islam under the Bahrī Mamlūks, 692-755/1293-1354. Bulletin of the School of Oriental and African Studies, University of London, Cambridge University Press, v. 39, n. 3, p. 552-569, 1976. Available at: http://www.jstor.org/stable/614714. Accessed on: 01 sep. 2020.

LONGVA, Anh Nga. From the Dhimma to the Capitulations: Memory and Experience of Protection in Lebanon. In: LONGVA, Anh Nga; ROALD, Anne Sofijie (Ed.). Religious Minorities in the Middle East: Domination, Self-Empowerment, Accommodation. Leiden e Boston: Brill, 2012. p. 47-69.

MAKDISI, Ussama. After 1860: Debating Religion, Reform, and Nationalism in the Ottoman Empire. International Journal of Middle East Studies, v. 34, n. 4, p. 601-617, 2002. Available at: https://www.jstor.org/stable/3879690. Accessed on: 01 sep. 2020.

MAKDISI, Ussama. The Culture of Sectarianism. First edition. Berkeley, Calif: University of California Press, 2000.

MAKDISI, Ussama. Artillery of Heaven: American Missionaries and the Failed Conversion of the Middle East. Ithaca and London: Cornell University Press, 2011.

MASTERS, Bruce. Christians Jews Ottoman Arab World: The Roots of Sectarianism. Revised ed. edition. New York: Cambridge University Press, 2004.

MASTERS, Bruce. Jizya. In: Encyclopedia of the Ottoman Empire. New York: Facts on File, 2009.

MASTERS, Bruce. The Establishment of the Melkite Catholic Millet in 1848 and the Politics of Identity in Tanzimat Syria. In: In: SLUGLETT, Peter; WEBER, Stefan. Syria and Bilad al-Sham under Ottoman Rule. Leiden: Brill, 2010. Leiden: Brill, 2010. p. 455-473.

O'SUlLIVAN, Shaun. Coptic Conversion and the Islamization of Egypt. Mamluk Studies Review, v. 10, n. 2, 2006. Available at: http://mamluk.uchicago.edu/MSR_X-2_2006-OSullivan. pdf. Accessed on: 01 sep. 2020.

PEIRCE, Leslie P. The Imperial Harem: Women and Sovereignty in the Ottoman Empire. New York: Oxford University Press, 1993.

POLLEY, Gabriel. 'Down with the Bell!' The Nāblus Uprising of April 1856. Romance, Revolution and Reform, n. 2, p. 12-35, 2020.

ROGAN, Eugene L. Sectarianism and Social Conflict in Damascus: The 1860 Events Reconsidered. Arabica, v. 51, n. 4, p. 493-511, 2004. Available at: http://www.jstor.org/stable/27667683. Accessed on: 01 sep. 2020.

ROY, Olivier. Holy Ignorance: When Religion and Culture Part Ways. Oxford: Oxford University Press, 2014.

SALIBI, Kamal. A House of Many Mansions: The History of Lebanon Reconsidered. London: IB Tauris, 1988

SHARKEY, Heather J. A History of Muslims, Christians, and Jews in the Middle East. Cambridge: Cambridge University Press, 2017.

SHAW, Stanford J. The Nineteenth-Century Ottoman Tax Reforms and Revenue System. International Journal of Middle East Studies, v. 6, n. 4, p. 421-459, 1975. Available at: www.jstor.org/ stable/162752. Accessed on: 31 Aug. 2020.

TRABOULSI, Fawwaz. A History of Modern Lebanon. London: Pluto Press, 2012.

WALBINER, Carten-Michael. The split of the Greek Orthodox patriarchate of Antioch (1724) and the emergence of a new identity in Bilad al-Sham as reflected by some Melkite historians of the eighteenth and early 20th centuries. Chronos, v. 7, p. 9-36, 2003.

ZUCKERMAN, Phil. Society Without God: What the Least Religious Nations Can Tell Us About Contentment. New York: New York University Press, 2008. 